\title{
JUAL BELI AIR SUMBER DALAM PERSPEKTIF ETIKA BISNIS ISLAM DI DESA CANDIWATES KECAMATAN PRIGEN KABUPATEN PASURUAN
}

\author{
Universitas Yudharta Pasuruan \\ Khoiriyah Hamidah ${ }^{1} \&$ Aslikhah $^{2}$ \\ midahhamidah530@gmail.com \& aslikhah@yudharta.ac.id
}

\begin{abstract}
Absract: Islam is a source of values and ethics in all aspects of overall buman life, including business discourse. One of the unique teachings of Islam is to teach its adherents to carry out economic practices based on Islamic norms and ethics. In this association of life every person has an interest in other people therefore rights and obligations arise. This interaction has many benefits, especially for the fulfillment of basic living needs such as eating, drinking and so forth. Especially in the case of drinking humans need water as a basic need. Water is a resource that is needed by all people in the world and becomes something that is very vital, even for the entire life of living things on this earth. As is the case of trading water in Candiwates Village, Prigen District, Pasuruan Regency. The method used in this research is a qualitative method using case studies. This research uses the method of collecting observation, interview and documentation data. The results of this study conclude that the application of Islamic business ethics in Candiwates Village, Prigen District, Pasuruan Regency is in accordance with the concept of Islamic business ethics which includes unity, justice, responsibility, free will and honesty. But they pay less attention to the implementation of social and environmental responsibility.
\end{abstract}

Keywords: Spring Water, Islamical Bussiness Ethic

\section{A. PENDAHULUAN}

Sejak manusia ada di muka bumi, maka sejak itu pula munculnya aktifitas-aktifitas didalam kehidupan manusia. Pada awal sejarahnya, aktivitas manusia hanya tertuju pada bagaimana cara memenuhi kebutuhan primer dalam rangka mempertahankan hidup. Dengan kata lain, aktivitas ekonomi yang pertama kali ada didalam kehidupan manusia. Seiring dengan berjalannya waktu, aktivitas manusia berkembang sejalan dengan tuntutan zaman dengan segala ragamnya.

Salah satu keunikan ajaran Islam adalah mengajarkan para penganutnya untuk melakukan praktik ekonomi yang berdasarkan kepada norma-norma dan etika Islam. Aspek ekonomi sangat penting peranannya dalam meningkatkan kesejahteraan hidup manusia, termasuk didalamnya tentang perdagangan. Perdagangan merupakan salah satu jenis usaha untuk meningkatkan kesejahteraan hidup manusia. Islam memang menghalalkan usaha perdagangan, perniagaan dan atau jual beli.

Konsep utama yang dijalankan oleh Rasulullah SAW. dalam perdagangan adalah kejujuran. Rasulullah SAW. dalam melakukan transaksi bisnis menggunakan sikap kejujuran sebagai etika dasar. Kejujuran Rasulullah 
SAW. dalam transaksi dilakukan dengan cara menyampaikan kondisi riil barang dagangannya. la tidak menyembunyikan kecacatan barang atau mengunggulkan barang dagangannya, kecuali sesuai dengan kondisi barang yang dijualnya.

Dalam pergaulan hidup ini setiap orang mempunyai kepentingan terhadap orang lain maka dari itu timbul hak dan kewajiban. Interaksi ini banyak manfaatnya terutama untuk pemenuhan kebutuhan hidup pokok seperti makan, minum dan lain sebagainya. Terutama dalam hal minum manusia memerlukan air sebagai kebutuhan pokok.

Air merupakan sumber daya yang dibutuhkan oleh seluruh manusia di dunia dan menjadi sesuatu yang sangat vital, bahkan untuk seluruh kehidupan makhluk hidup di bumi ini. Semua makhluk hidup tidak bisa hidup tanpa adanya air, karena air telah menjadi salah satu sumber kehidupan yang sangat penting dan kehidupannya sangat tergantung pada air, karena memang air adalah kebutuhan yang sangat pokok dan mendasar dalam kehidupan. Tidak hanya manusia yang membutuhkan air, makhluk lain seperti hewan dan tumbuhan juga sangat membutuhkan keberadaan air untuk keberlangsungan hidupnya.

Tidak selamanya air tersedia dalam volume yang cukup terutama di daerah tandus serta kekeringan pada musim kemarau. Hal ini mengakibatkan masyarakat yang ada di daerah tersebut harus membeli air bersih apabila tidak ingin kesusahan mencari sumber air sampai jauh. Namun kegiatan tersebut memberikan kemudahan dan memberikan keuntungan bagi pengusaha yang mempunyai truk tangki seperti di Desa Candiwates Kecamatan Prigen Kabupaten Pasuruan ini.

Menjamurnya sumur artesis setidaknya terdapa 10 hingga 15 sumur artesis yang dikelola para pengusaha air curah di desa sekitar Kecamatan Prigen, Kabupaten Pasuruan, Jawa Timur, tanpa ada pengawasan yang ketat dari Pemerintah Kabupaten (Pemkab) Pasuruan, membuat debit sumber air di sejumlah titik, yakni di Desa Candiwates, Kecamatan Prigen, mulai turun secara drastis mencapai 90 persen. Untuk memenuhi kebutuhan warga, pihak desa sejatinya memiliki jaringan pipa yang bersumber dari sumur artesis. Bahkan untuk irigasi juga mulai berkurang secara signifikan. Tentu saja, hal ini berimbas pada warga sekitarnya. Kawasan tersebut bahkan terancam krisis air. Padahal sumber air di lereng Gunung Arjuno-Welirang, tahun 1990-2000 sumbernya melimpah hingga meluber ke aliran irigasi sekitar.

Forum Pemerhati Kelestarian Air Kabupaten Pasuruan, Abdus Syukur, mendesak pemerintah untuk segera turun tangan. Sebab, pemerintah berkewajiban untuk melindungi warganya dari berbagai bahaya dan ancaman, termasuk ancaman krisis air bersih. Bahkan, banyaknya ekplorasi yang tak terkendali dibeberapa tempat, Pemerintah Kabupaten (Pemkab) Pasuruan tak meresponnya dan terkesan dibiarkan tanpa adanya tindakan. Menurutnya, pemerintah daerah setempat, yakni Pemkab Pasuruan, tidak boleh lepas 
tangan dengan alasan kewenangan. Lantaran eksplorasi air sepenuhnya jadi kewenangan Pemprov Jatim. ${ }^{3}$

Tujuan penelitian diantaranya untuk mengetahui praktik jual beli air sumber di Desa Candiwates Kecamatan Prigen Kabupaten Pasuruan. Untuk mengetahui penerapan jual beli air sumber di Desa Candiwates Kecamatan Prigen Kabupaten Pasuruan dalam perspektif etika bisnis Islam.

\section{B. KAJIAN PUSTAKA}

\section{Jual Beli}

Jual beli dalam istilah fiqih disebut al-bay' yang berarti menjual, mengganti dan menukar sesuatu dengan sesuatu yang lain. Kata "al-bay" dalam bahasa Arab terkadang digunakan untuk pengertian lawannya, yaitu kata asy-syira' (beli), kata al-bay' yang berati jual, tetapi sekaligus juga berarti beli, sehingga dalam adat sehari-hari, istilah al-bay' berarti jual beli.

Segi istilah ulama Hanafiyah mendefinisikan bahwa jual beli adalah saling menukar harta dengan harta melalui cara tertentu atau tukar menukar sesuatu yang diingini dengan yang sepadan memalui cara tertentu yang bermanfaat. Menurut jumhur Ulama bahwa bentuk jual beli adalah saling menukar harta dengan harta dalam bentuk pemindahan kepemilikan.

Berdasarkan tiga definisi tersebut, dapat disimpulkan bahwa yang dinamakan jual beli adalah saling tukar menukar harta dengan cara ijab qabul yang berakibat terjadinya pemindahan kepemilikan.

\section{Dasar Hukum Jual Beli}

Jual beli sebagaimana sarana taawun atau tolong menolong antara sesama umat manusia yang mempunyai landasan kuat dalam Al-Qur'an dan Sunnah Nabi Muhammad SAW. Terdapat beberapa ayat Al-Qur'an yang membahas tentang jual beli, ${ }^{4}$ di antaranya dalam Q.S Surat An-Nisa' Ayat 29:

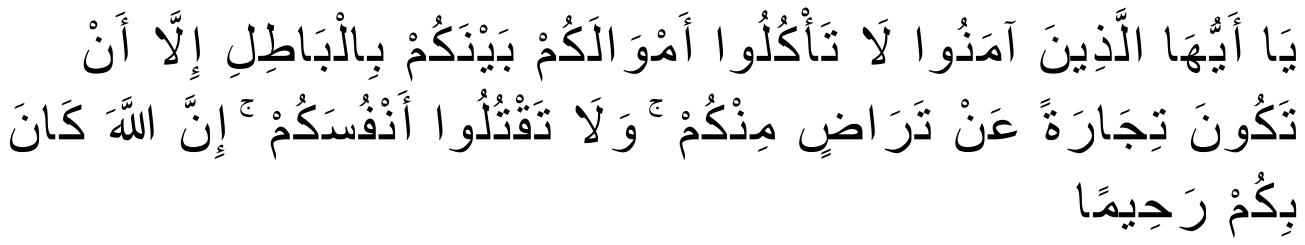

"Hai Orang-orang yang beriman, janganlah kamu saling memakan harta sesamamu dengan jalan yang bathil, kecuali dengan jalan perniagaan yang Berkah dengan suka sama suka di antara kamu. Dan janganlah kamu membunuh dirimu; Sesungguhnya Allah adalah Maha Penyayang kepadamu".

Reportasenews.com, "Sumber Artesis Ilegal Menjamur, Warga Terancam Krisis Air" (http://reportasenews.com/sumur-artesis-ilegal-menjamur-warga-terancam-krisis-air/, Diakses pada 10 Desember 2019, 2017)

${ }^{4}$ Nasrun Hareon, Fiqh Muamalah, Jakarta: Gaya Media Patama, 2007, 113. 
Begitu juga dijelaskan dalam hadis Nabi yang diriwayatkan oleh Imam Ahmad, menyatakan bahwasannya Nabi SAW ketika di tanya tentang usaha apa yang baik beliau menjawab:

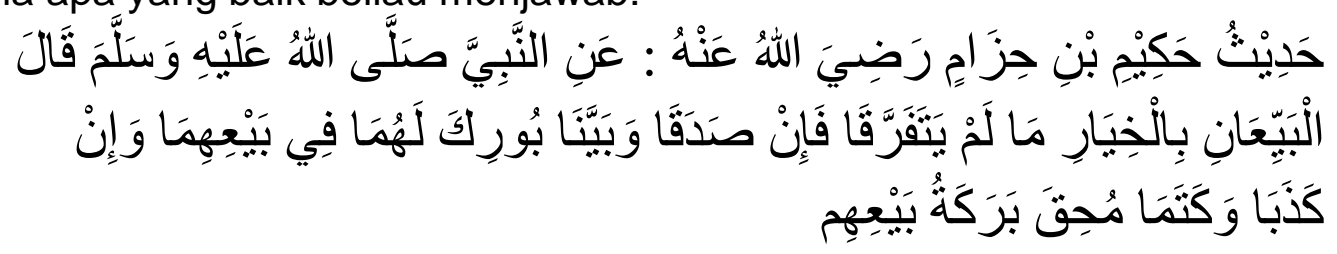

"Diriwayatkan dari pada Hakim bin Hizam ra. Katanya: Nabi SAW bersabda: Penjual dan pembeli diberi kesepakatan berpikir selagi mereka belum berpisah. Sekiranya mereka jujur serta membuat penjelasan mengenai barang yang dijual belikan, mereka akan mendapat berkah dalam jual beli mereka. Sekiranya mereka menipu dan merahasiakan mengenai apa-apa yang harus diterangkan tentang barang yang dijual belikan akan terhapus keberkahannya." (HR. Ahmad) ${ }^{5}$

Ulama telah sepakat bahwa jual beli diperbolehkan dengan alasan bahwa manusia tidak akan mampu mencukupi kebutuhan dirinya sendiri, tanpa bantuan orang lain. Namun demikian, bantuan atau barang milik orang lain yang dibutuhkannya itu harus diganti dengan barang lainnya yang sesuai. ${ }^{6}$

\section{Air}

Air adalah zat cair yang tidak mempunyai rasa, warna dan bau, terdiri dari hidrogen dan oksigen dengan rumus $\mathrm{H} 2 \mathrm{O}$. Air adalah semua air yang terdapat pada, di atas, ataupun di bawah permukaan tanah, termasuk dalam pengertian ini air permukaan, air tanah, air hujan, dan air laut yang berada di darat (UU No 7 Tahun 2004 pasal 1 ayat 2).

Air sumber yang dimaksud disini adalah mata air artesis yang berasal dari lapisan air dalam posisi tertekan. Air artesis berusaha untuk menembus lapisan rapat air dan keluar ke permukaan bumi.

\section{Etika Bisnis Islam}

Adapun istilah etika, secara teoritis dapat dibedakan ke dalam dua pengertian. Pertama, etika berasal dari bahasa yunani ethos yang berarti adat istiadat atau kebiasaan. Dalam pengertian ini etika berkaitan dengan kebiasaan hidup yang baik, baik pada diri seseorang maupun pada suatu masyarakat atau kelompok masyarakat yang diwariskan dari satu orang ke rang lain atau dari satu generasi ke generasi yang lain. Kebiasaan ini lalu terungkap dalam perilaku berpola yang terus berulang sebagai sebuah kebiasaan.

\footnotetext{
${ }^{5}$ Imam Ahmad bin Hambal, Musnad Imam Ahmad bin Hambal asy-Syamiyin, Jil. 4 (Beirut- Al-kutub AlIlmiah, t.t), 284.

${ }^{6}$ Rachmad Syafe'i, Fiqh Muamalah. Bandung: CV. Pustaka Setia, 2011, 75.
} 
Sementara itu, bisnis memiliki pengertian yang sangat luas. Aktifitas bisnis bukan saja kegiatan dalam rangka menghasilkan barang dan jasa, tetapi juga termasuk kegiatan mendistribusikan barang dan jasa tersebut ke pihak-pihak yang memerlukan serta aktivitas lain yang mendukung kegiatan produksi dan distribusi tersebut. ${ }^{7}$ Dengan demikian, etika bisnis berarti seperangkat prinsip dan norma di mana para pelaku bisnis harus komit padanya dalam bertransaksi, berperilaku, dan berelasi guna mencapai 'daratan' atau tujuan-tujuan bisnisnya dengan selamat. ${ }^{8}$

Adapun bisnis Islami dapat diartikan sebagai serangkaian aktifitas bisnis dalam berbagai bentuknya yang tidak dibatasi jumlah (kuantitas), kepemilikan hartanya (barang/jasa), termasuk profitnya, namun dibatasi dalam cara perolehan dan pendayagunaan hartanya (ada aturan halal dan haram).

Dari uraian diatas, dapatlah kita mendefinisikan etika bisnis Islam sebagai seperangkat nilai tentang baik dan buruk, benar dan salah dalam dunia bisnis berdasarkan pada prinsip-prinsip moralitas dan juga Al-Quran dan Hadits yang telah dicontohkan oleh Rasulullah saw. ${ }^{9}$ Adapun menurut Prof. Dr. Amin Suman SH, MM, yang dimaksud etika bisnis Islam adalah konsep tentang usaha ekonomi perdagangan dari sudut pandang baik dan buruk serta benar dan salah menurut standar akhlaq Islam. ${ }^{10}$

\section{Prinsip Dasar Etika Bisnis Islam}

Prinsip dasar etika bisnis Islam tersebut ialah:

a. Kesatuan

Kesatuan merupakan cerminan dari konsep tauhid, yang merupakan dimensi vertikal Islam. Konsep tauhid menggabungkan semua aspek yang berbeda-beda dalam kehidupan muslim, yakni ekonomi, politik, agama, dan masyarakat, serta menekankan gagasan mengenai konsistensi dan keteraturan. Konsep kesatuan ini merupakan konsep yang paling mendalam pada diri seorang muslim, karena seorang muslim memandang apapun di dunia sebagai milik Allah, karena hanya Allah yang Maha Kuasa dan Maha Esa, karena ia percaya bahwa hanya Allah yang dapat menolong dan pengaruh paling besar bahwa kaum muslim akan mentaati dan melaksanakan hukum Allah. ${ }^{11}$

b. Keseimbangan

\footnotetext{
${ }^{7}$ Sukrisno Agoes dan I Cenik Ardana, Etika Bisnis dan Profesi, Jakarta: Salemba Empat, 2014, 76.

${ }^{8}$ Faisal Badroen, et al, Etika Bisnis Dalam Islam, Jakarta: Kencana, 2006, 15.

${ }^{9}$ Muhammad, Etika Bisnis Islam, Yogyakarta: UPP AMP YKPN, 2004, 37.

${ }^{10}$ Muhammad dan Fauroni Lukman, Visi Al-Qur'an: Tentang Etika Bisnis, Jakarta: Salemba Diniyah, 2002, 11 .

${ }^{11}$ Beekun, Etika Bisnis Islami, Yogyakarta: Pustaka Pelajar, 2004, 33-34.
} 
Keseimbangan atau 'adl menggambarkan dimensi horizontal ajaran Islam dan berhubungan dengan segala sesuatu di alam semesta. Hukum dan keteraturan yang kita lihat di alam semesta merefleksikan konsep keseimbangan yang rumit ini. ${ }^{12}$ Penerapan konsep keseimbangan ini sebagai contoh adalah Allah memperingatkan para pengusaha muslim untuk menyempurnakan takaran. Sangat menarik untuk mengetahui makna 'adl adalah keadilan atau kesetaraan. Secara keseluruhan Islam ingin mengekang kecenderungan sikap serakah manusia dan kecintaannya untuk memiliki barang-barang. ${ }^{13}$

c. Kehendak Bebas

Kebebasan merupakan bagian terpenting dalam nilai etika bisnis Islam, tetapi kebebasan itu tidak merugikan kepentingan kolektif. Kepentingan individu dibuka lebar, tidak ada batasan pendapat bagi seseorang mendorong manusia untuk aktif berkarya dan bekerja dengan segala potensi yang dimilikinya, kecenderungan manusia untuk terus-menerus memenuhi kebutuhan pribadinya yang tak terbatas dikendalikan dengan adanya kewajiban setiap individu terhadap masyarakatnya melalui zakat, infak, dan sedekah. ${ }^{14}$ Penerapan konsep kehendak bebas dalam etika bisnis Islam ialah manusia memiliki kebebasan untuk membuat kontrak dan menepatinya ataupun mengingkarinya. Seorang muslim yang telah menyerahkan hidupnya pada kehendak Allah akan menepati semua kontrak yang telah ia buat. $^{15}$

d. Tanggung Jawab

Islam sangat menekankan pada konsep tanggung jawab, walaupun tidaklah berarti mengabaikan kebebasan individu, ini berarti bahwa yang dikehendaki ajaran Islam adalah kebebasan yang bertanggung jawab. Manusia harus berani mempertanggung jawabkan segala pilihannya tidak saja di hadapan manusia, bahkan yang paling penting adalah di hadapan Allah. Bisa saja karena kelihaiannya, manusia mampu melepaskan tanggung jawab perbuatannya yang merugikan manusia, namun kelak ia tidak akan pernah lepas dari tanggung jawab di hadapan Allah Yang Maha Mengetahui. ${ }^{16}$

e. Kebenaran: Kebajikan dan Kejujuran

\footnotetext{
${ }^{12}$ Muhammad, Etika Bisnis Islami (Yogyakarta: Akademi Manajemen Perusahaan YKPN, 2004), 55.

${ }^{13}$ Beekun, Etika Bisnis Islami, Yogyakarta: Pustaka Pelajar, 2004, 37.

${ }^{14}$ Abdul Aziz, Etika Bisnis Perspektif Islam Cet. 1, Bandung: Alfabeta, 2013, 46.

${ }^{15}$ Beekun, Etika Bisnis Islami, Yogyakarta: Pustaka Pelajar, 2004, 39.

${ }^{16}$ Muhammad Djakfar, Etika Bisnis Islami Tataran Teoritis dan Praktis (Malang: UIN Malang Press, 2008), 67-68.
} 
Kebenaran dalam konteks ini selain mengandung makna kebenaran, mengandung pula dua unsur yaitu kebajikan dan kejujuran. Dalam konteks bisnis kebenaran dimaksudkan sebagai niat, sikap dan perilaku benar meliputi proses transaksi, proses mencari atau memperoleh komoditas pengembangan maupun dalam proses menetapkan keuntungan. Dengan prinsip kebenaran ini maka etika bisnis Islam sangat menjaga dan berlaku preventif terhadap kemungkinan adanya kerugian salah satu pihak yang melakukan transaksi, kerja sama atau perjanjian dalam bisnis. ${ }^{17}$

\section{METODE}

\section{Pendekatan dan Jenis Penelitian}

Jenis penelitian yang digunakan penulis dalam hal ini adalah pendekatan kualitatif. Penelitian kualitatif adalah penelitian yang bermaksud untuk memahami fenomena apa yang dialami oleh subjek penelitian. ${ }^{18}$

Sedangkan pendekatan yang digunakan penulis dalam hal ini adalah pendekatan studi kasus yaitu studi yang mendalam hanya pada satu kelompok orang atau peristiwa. Teknik ini hanyalah sebuah deskripsi terhadap individu. ${ }^{19}$

\section{Kehadiran Peneliti}

Dalam penelitian ini, peneliti bertindak sebagai pengumpul data dan sebagai instrumen aktif dalam upaya mengumpulkan data-data di lapangan.

\section{Sumber Data}

a. Data Primer

Data primer adalah sumber data yang langsung memberikan data kepada pengumpul data. ${ }^{20}$ Dalam penelitian ini data primer yang dimaksud adalah mereka yang menjadi objek penelitian ini, yaitu wawancara secara langsung kepada penjual, pembeli dan warga sekitar yang terlibat dalam jual beli air sumber yang ada di Desa Candiwates Kecamatan Prigen Kabupaten Pasuruan.

b. Data Sekunder

Data sekunder adalah sumber data yang tidak langsung memberikan data kepada pengumpul data. ${ }^{21}$ Pada penelitian ini data sekunder yang dimaksud adalah data yang diambil dari Al-Qur'an, hadits, buku dan website yang sesuai dengan tema yang diangkat dan perlu dipertanggungjawabkan.

\section{Teknik Pengumpulan Data}

\footnotetext{
${ }^{17}$ Abdul Aziz, Etika Bisnis Perspektif Islam Cet. 1, Bandung: Alfabeta, 2013, 46-47.

${ }^{18}$ Lexy J. Moleong, Metodologi Penelitian Kualitatif (Bandung: PT. Remaja Rosdakarya, 2009), 6.

${ }^{19}$ M. Burhan Bungin. Penelitian Kualitatif, Edisi Ke-2, (Jakarta: Prenada Media Group, 2007), 132.

${ }^{20}$ Sugiyono, Metode Penelitian Kuantitatif Kualitatif \& RND, Bandung: Alfabeta, 2010, 136.

${ }^{21}$ Ibid, 138.
} 
Dalam mengumpulkan data pada penelitian ini, peneliti akan menggunakan beberapa metode yaitu :

a. Metode Observasi

Observasi adalah pengamatan dan pencatatan yang sistematis terhadap gejala-gejala yang diteliti. ${ }^{22}$ Metode ini dilakukan dengan mengumpulkan data melalui pengamatan secara langsung kepada penjual, konsumen dan warga sekitar di Desa Candiwates Kecamatan Prigen Kabupaten Pasuruan.

b. Metode Wawancara

Wawancara adalah merupakan pertemuan dua orang untuk bertukar informasi dan ide melalui tanya jawab, sehingga dapat dikontruksikan makna dalam suatu topik tertentu. Wawancara digunakan sebagai teknik pengumpulan data apabila peneliti ingin melakukan studi pendahuluan untuk menemukan permasalahan yang harus diteliti, tetapi juga apabila peneliti ingin mengetahui hal-hal dari responden yang lebih mendalam. ${ }^{23}$

c. Metode Dokumentasi

Dokumen merupakan catatan peristiwa yang sudah berlalu. Dokumen bisa berbentuk tulisan dan gambar. Studi dokumen merupakan pelengkap dari penggunaan metode observasi dan wawancara dalam penelitian kualitatif.

\section{HASIL DAN PEMBAHASAN}

\section{Praktik Jual Beli Air Sumber di Desa Candiwates Kecamatan Prigen} Kabupaten Pasuruan

Jual beli air sumber di Desa Candiwates Kecamatan Prigen Kabupaten Pasuruan ini berawal dari sumber air yang melimpah dan permintaan air dari luar daerah sangat banyak. Setidaknya terdapat 10 sampai 15 sumur artesis yang dikelola para pengusaha air sumber. Oleh mereka air sumber itu dijual dengan menggunakan mobil tangki ke luar daerah. Adapun praktik dalam jual beli air sumber di Desa Candiwates Kecamatan Prigen Kabupaten Pasuruan sebagai berikut:

a. Transaksi Jual Beli

Transaksi jual beli yang digunakan pada jual beli air sumber di Desa Candiwates Kecamatan Prigen Kabupaten Pasuruan ini ada dua cara yaitu dengan cara pesan lewat handphone (online) dan cara langsung datang ke tempat (offline).

b. Pengiriman

Pengiriman dilakukan sesuai dengan urutan pemesanan dengan konsumen yang lain sedangkan biaya untuk pengiriman ditentukan oleh

\footnotetext{
${ }^{22}$ Husaini Usman, Metodologi Penelitian Soaial, Ed 2, Cet. 3, Jakarta: Bumi Aksara, 2009, 52.

${ }^{23}$ Sugiyono, Metode Penelitian Kuantitatif Kualitatif \& RND, Bandung: Alfabeta, 2010), 231.
} 
jauh dekatnya jarak atau seberapa banyak solar yang dihabiskan. Selain menggunakan jasa antar penjual juga memperbolehkan konsumen membeli dengan membawa truk tangki mereka sendiri.

\section{Penerapan Etika Bisnis Islam pada Jual Beli Air Sumber di Desa} Candiwates Kecamatan Prigen Kabupaten Pasuruan

Berdasarkan dari hasil penelitian di lapangan, dengan teknik observasi dan wawancara kepada para penjual air sumber, pembeli dan beberapa masyarakat sekitar terkait dengan etika bisnis Islam yang dicontohkan oleh Rasulullah SAW dalam berdagang apakah sifat-sifat tersebut diterapkan atau tidak, oleh para penjual air sumber yang ada di Desa Candiwates Kecamatan Prigen Kabupaten Pasuruan.

Adapun hal-hal yang harus diterapkan dalam berbisnis secara Islam:

a. Kesatuan

Kesatuan sebagaimana terefleksikan dalam konsep tauhid yang memadukan keseluruhan aspek-aspek kehidupan muslim baik dalam bidang ekonomi, politik, sosial menjadi keseluruhan yang homogen, serta mementingkan konsep konsistensi dan keteraturan yang menyeluruh. Dari konsep ini maka Islam menawarkan keterpaduan agama, ekonomi, dan sosial demi membentuk kesatuan. ${ }^{24}$ Masalah kesatuan ini juga telah dijelaskan dalam A-Qur'an surat Al-Imran ayat 103:

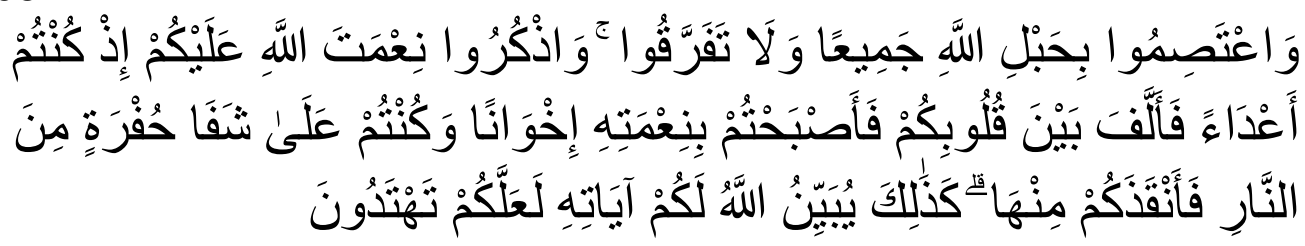

"Dan berpeganglah kamu semuanya kepada tali (agama) Allah, dan janganlah kamu bercerai berai, dan ingatlah akan nikmat Allah kepadamu ketika kamu dahulu (masa Jahiliyah) bermusuhmusuhan, maka Allah mempersatukan hatimu, lalu menjadilah kamu karena nikmat Allah, orang-orang yang bersaudara; dan kamu telah berada di tepi jurang neraka, lalu Allah menyelamatkan kamu dari padanya. Demikianlah Allah menerangkan ayat-ayat-Nya kepadamu, agar kamu mendapat petunjuk."

Prinsip kesatuan yang ditunjukkan oleh para penjual air sumber yang ada di Desa Candiwates Kecamatan Prigen Kabupaten Pasuruan adalah dengan saling membantu ketika ada salah satu penjual yang mengalami masalah maka penjual yang lain membantu.

b. Keseimbangan (keadilan)

\footnotetext{
${ }^{24}$ Abdul Aziz, Etika Bisnis Perspektif Islam, 46.
} 
Prinsip keadilan merupakan sebuah sikap yang tidak membedabedakan pembeli yang merupakan salah satu bentuk aplikasi dari sifat adil.

Jual beli air sumber yang ada di Desa Candiwates Kecamatan Prigen Kabupaten Pasuruan juga mengedepankan sifat adil seperti apabila ada banyak pembeli tidak memilih-milih pembeli untuk diberi layanan yang lebih sesuai dengan urutan pemesanan karena memang prinsipnya semua pembeli itu sama.

c. Kehendak Bebas

Kebebasan berarti bahwa manusia sebagai individu dan kolektif mempunyai kebebasan penuh untuk melakukan aktivitas bisnis. Manusia dikatakan bebas mengandung dua pengertian, yaitu ia mampu untuk menentukan diri sendiri dan ia tidak dibatasi oleh orang lain atau masyarakat dalam kemungkinannya untuk menentukan diri. Seperti yang dijelaskan dalam Al-Qur'an surat Al-Maidah ayat 1:

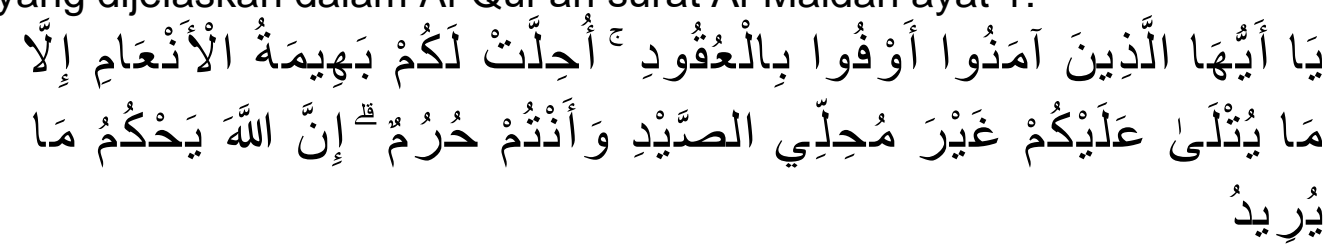

"Hai orang-orang yang beriman, penuhilah akad-akad itu. Dihalalkan bagimu binatang ternak, kecuali yang akan dibacakan kepadamu. (Yang demikian itu) dengan tidak menghalalkan berburu ketika kamu sedang mengerjakan haji. Sesungguhnya Allah menetapkan hukum-hukum menurut yang di kehendakiNya."

Prinsip kehendak bebas yang diwujudkan oleh responden dengan tidak memberikan harga dibawah harga standar untuk menarik pembeli dan memberikan kebebasan kepada pembeli untuk mendapatkan barang sesuai dengan selera mereka.

d. Tanggung Jawab

Manusia diciptakan di dunia mempunyai satu peran untuk mengelola kehidupannya sebaik mungkin. Dan semua aspek kehidupannya bukan suatu aspek kehidupannya bukan suatu yang terbebas dari sebuah tanggung jawab. Tanggung jawab berarti, bahwa manusia sebagai pelaku bisnis mempunyai tanggung jawab moral kepada Tuhan. Harta sebagai komoditi bisnis dalam Islam, adalah amanah Tuhan yang harus dipertanggungjawabkan di hadapan Tuhan. Seperti yang telah dijelaskan dalam Al- Qur'an :

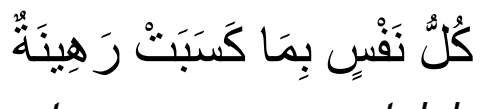

"Tiap tiap diri bertanggung jawab atas apa yang telah diperbuatnya." (QS. Al- Mudatsir 74:38) 
Dari ayat diatas, telah dijelaskan bahwa kita sebagai manusia apabila melakukan suatu perbuatan maka dianjurkan untuk bertanggung jawab atas perbuatan kita, baik itu perbuatan baik ataupun perbuatan buruk karena tanggung jawab termasuk kewajiban.

Bentuk tanggungjawab yang dilakukan oleh penjual air sumber berupa menjual air sumber layak untuk dikonsumsi, serta tidak menjual barang yang dapat merugikan pembeli.

e. Kebenaran: Kebajikan dan Kejujuran

Prinsip ini mengajarkan untuk melakukan perbuatan yang dapat mendatangkan manfaat kepada orang lain, tanpa harus aturan yang mewajibkan atau memerintahkannya untuk melakukan perbuatan itu, atau dalam istilah lainnya adalah beribadah maupun berbuat baik seakan-akan melihat Allah, jika tidak seperti itu, maka yakinlah bahwa Allah melihat apa yang kita kerjakan. Perilaku kebenaran dalam bisnis secara tegas dijelaskan dalam konteks perbendaharaan bisnis (klasik) agar pengusaha muslim menyempurnakan takaran bila menakar dan menimbang dengan neraca yang benar, karena hal itu merupakan perilaku yang terbaik dan membawa akibat yang terbaik pula. Sebagaimana Allah SWT berfirman:

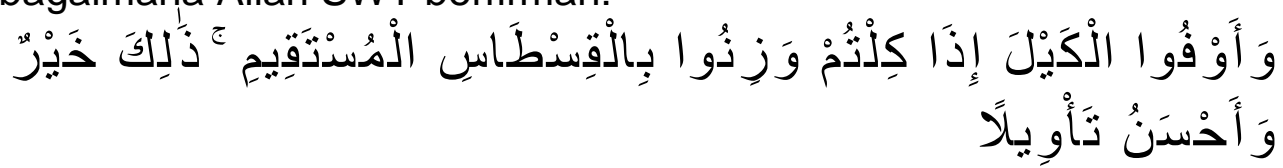

"Dan sempurnakanlah takaran apabila kamu menakar, dan timbanglah dengan neraca yang benar. Itulah yang lebih utama (bagimu) dan lebih baik akibatnya". (QS.Al Isra':35) ${ }^{25}$

Menurut peneliti perilaku para pedagang sudah sesuai dengan prinsip keseimbangan atau keadilan dalam menjalankan transaksi jual beli dengan tidak mengurangi takaran air sumber.

Berdasarkan hasil penelitian baik itu berupa hasil wawancara, pengamatan langsung di lapangan dalam hal pelaksanaan tanggung jawab sosial dan lingkungan pada jual beli air sumber di Desa Candiwates Kecamatan Prigen Kabupaten Pasuruan terhadap masyarakat dapat digambarkan dari kegiatan di berbagai bidang. Dalam hukum Islam berdasarkan penelitian dan nash-nash maupun hadits diketahui bahwasannya hukum syari'at Islam mencakup diantaranya kemaslahatan manusia di mana dalam hal ini pula kegiatan tanggung jawab sosial dan lingkungan ini dipandang sebagai kegiatan untuk kemaslahatan manusia. Allah SWT berfirman:

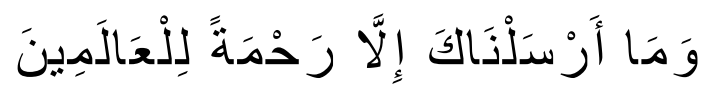

${ }^{25}$ Departemen Agama RI, Al Qur'an dan Terjemahnya, Bandung: CV Diponegoro, 2005, 198. 
Artinya: "Dan tiadalah Kami mengutus kamu, melainkan untuk (menjadi) rahmat bagi semesta alam.” (QS. Al-Anbiyaa': 107)

Adapun bentuk pengaruh tersebut antara lain:

a. Mengelola usaha pelestarian lingkungan dengan cara penghijauan untuk mencegah erosi tanah dan membantu resapan air. Program ini mempunyai misi yaitu melakukan konservasi sebagai upaya dan peran serta pelestarian lingkungan.

b. Pembangunan dan perbaikan rumah ibadah seperti perbaikan dan pembangunan masjid atau mushollah.

c. Pengembangan sarana dan prasarana umum seperti perbaikan jalan.

d. Kegiatan sosial dan hari besar keagamaan: pelaksanaan kegiatan hari besar keagamaan dan kenegaraan, dll.

\section{E. KESIMPULAN}

Berdasarkan pembahasan di atas, peneliti dapat menarik kesimpulan berdasarkan rumusan masalah, yaitu:

1. Praktik jual beli air sumber di Desa Candiwates Kecamatan Prigen Kabupaten Pasuruan menjadi kegiatan usaha yang produknya banyak diminati ditengah-tengah masyarakat luas mengingat jumlah penduduk di setiap daerah terus bertambah. Sehingga menjadikan para penjual air sumber meningkatkan proses usahanya agar dapat memenuhi permintaan yang sangat tinggi dan memberikan keuntungan bagi usaha air sumber mereka.

2. Penerapan etika bisnis Islam di Desa Candiwates Kecamatan Prigen Kabupaten Pasuruan sudah diterapkan seperti tentang kesatuan, keadilan, tanggung jawab, kehendak bebas dan jujur. Tetapi mereka kurang memperhatikan dalam hal pelaksanaan tanggung jawab sosial dan lingkungan.

\section{DAFTAR PUSTAKA}

Agoes, Sukrisno dan I Cenik Ardana. 2014. Etika Bisnis dan Profesi. Jakarta: Salemba Empat.

Aziz, Abdul. 2013. Etika Bisnis Perspektif Islam Cet. 1, Bandung: Alfabeta.

Badroen, Faisal dkk. 2006. Etika Bisnis dalam Islam. Jakarta: Kencana Prenada Media Group.

Beekun, Rafik Issa. 2004. Etika Bisnis Islami. Yogyakarta: Pustaka Pelajar. 
Bungin, Burhan. 2007. Penelitian Kualitatif: Komunikasi, Ekonomi, Kebijakan Publik, dan IImu Sosial Lainnya. Jakarta: Kencana Prenada Media Group.

Departemen Agama RI. 1985. Al-Qur'an dan Terjemahannya. Semarang: Toha Putra.

Djakfar, Muhamamad. 2007. Etika Bisnis Dalam Persepektif Islam. Malang: UIN-Malang Press.

Haroen, Nasrun. 2007. Fiqh Muamalah. Jakarta: Gaya Media Patama.

Ibn Hambal, Ahmad. Musnad Imam Ahmad bin Hambal asy-Syamiyin Jil. 4. Beirut: Al-Kutub Al-IImiah, t.t.

Moleong, Lexy J. 2009. Metode Penelitian Kualitatif, Cet. 21. Bandung: PT Remaja Rosdakarya.

Muhammad. 2004. Etika Bisnis Islam. Yogyakarta: Akademi Manajemen Perusahaan YKPN.

Muhammad, Fauroni Lukman. 2002. Visi Al-Qur'an: Tentang Etika Bisnis. Jakarta: Salemba Diniyah.

Reportasenews.com, "Sumber Artesis Ilegal Menjamur, Warga Terancam Krisis Air", http://reportasenews.com/sumur-artesis-ilegal-menjamur-wargaterancam-krisis-air/, (Diakses pada 10 Desember 2019, 2017)

Sugiyono. 2010. Metode Penelitian Kuantitatif Kualitatif \& RND. Bandung: Alfabeta.

Syafe'i, Rachmad. 2011. Fiqh Muamalah. Bandung: CV. Pustaka Setia..

Usman, Husaini. 2009. Metodologi Penelitian Soaial, Ed 2, Cet. 3. Jakarta: Bumi Aksara. 